\title{
СОЦІАЛЬНИЙ ОБЛІК ЯК ІНСТРУМЕНТ СОЦІАЛЬНОЇ ВІДПОВІДАЛЬНОСТІ ПІДПРИЕМСТВ
}

DOI: $10.32620 /$ cher.2020.1.10

Постановка проблеми. Розкриття інформації про соціальну відповідальність вимагає формування моделі соціального обліку та обгрунтування специфічних інструментів, що дозволяють відображати доходи та витрати, пов'язані із соціально відповідальною діяльністю підприємства.Метою cтатті наукове обгрунтування передумов, вихідних положень та пріоритетних напрямків організації соціального обліку. Об'єктом дослідження виступає процес обліку соціальної відповідальності. $M е т о д u$, використані у дослідженні: наукового узагальнення, логічно-змістовний, індукції та дедукції, аналізу.Гіпотезою дослідженняє припущення, що соціальний облік повинен бути орієнтований на розкриття інформації щодо соціально відповідальної діяльності для різних користувачів і складання інтегрованої звітності. Виклад основного матеріалу. Підвищення соціальної відповідальності підприємств обумовлює необхідність трансформації бухгалтерського обліку з метою надання прозорої інформації про соціальну та екологічну діяльність для різних груп користувачів, а також складання інтегрованої звітності. Підгрунтям розвитку методології соціального обліку є концепції соціальної відповідальності, сталого розвитку, створення цінності, уточнені об'єкти і класифікація соціально відповідальних витрат. Доведено, що раціональною є модель комбінованого соціально орієнтованого обліку, що передбачає паралельне відображення у бухгалтерському обліку господарських операцій, пов'язаних із соціальною діяльністю на основі додаткової системи аналітичних рахунків, формування показників фінансової і соціальної звітності. 3 метою раціональної організації пооб'єктного соціального обліку запропоновано класифікацію об'єктів в контексті реалізації концепції цінності та соціально відповідальних витрат. Оригінальність та практичне значеннявизначаються розробкою вихідних положень розвитку методології соціального обліку, орієнтованого на забезпечення соціальної відповідальності підприємства танауково-методичних рекомендацій щодо класифікації соціально відповідальних витрат. Висновки та перспективи подальших досліджень. Враховуючи потреби різних зацікавлених осіб у розкритті інформації щодо результативності економічної, соціальної і екологічної діяльності господарюючих суб'єктів,подальші дослідження будуть присвячені висвітленню методичних положень щодо організаціїобліку соціально відповідальних витрат.

\section{Ключові слова:}

соціальний облік, нефінансова звітність, потреби користувачів, міжнародні стандарти соціального обліку, соціально відповідальні витрати, об'єкти соціального обліку.

\section{SOCIAL ACCOUNTING AS A TOOL OF CORPORATE SOCIAL RESPONSIBILITY}

Formulation of problem. Disclosing information about the social responsibility reguires the formation of social accounting model and the justification of specific tools that allow to reflect incomes and expenses that are due to socially responsible activity of enterprise. The aim of the research is scientific basis for preconditions, underlying assumptions, priority directions oforganization of social accounting. The $o b$ ject of the research is the process of accountingfor social responsibility. Methods, used in research: scientific generalization, logical and informative, induction, deduction, analysis. The hypothesis of the research is the assumption that social accounting should be oriented to disclosing information regarding socially re-

${ }^{1}$ Костирко Руслан Олександрович, д-р екон. наук, професор, професор кафедри «Облік та оподаткування», ДВНЗ «Університет банківської справи», м. Київ, Україна.

Kostyrko Ruslan, Doctor of Economic Sciences, Professor, Professor of Accounting and taxation Department, UniversityofBanking, Kyiv, Ukraine.

ORCID ID: 0000-0001-9247-3363

e-mail: ruslankostyrko@gmail.com

${ }^{2}$ Прозоров Денис Вікторович, аспірант кафедри «Облік та оподаткування», ДВНЗ «Університет банківської справи», м. Київ, Україна.

Prozorov Denys, Postgraduate of Accounting and taxation Department University of Banking, Kyiv, Ukraine.

ORCID ID: 0000-0002-2459-2499

e-mail: den.proz.ua@gmail.com 
sponsible activity for different stakeholders and formation of integrated reporting. The statement of basic materials. The increasing social responsibility of enterprises specifies the necessity of the transformation of accounting in order to give transparent information about social and ecological activity for different groups of users, as well as the formation of integrated reporting. The base of development ofsocial accountingmethodology is concept of social responsibility, sustainable development, creation of value, object and classification of socially responsible expenses are specified. It is proved that the model of combined socially oriented accounting that includes the parallel reflection business operations in accounting that are due to social activity based on additional system of analytical accounts, the formation of indicators of financial and social reporting is rational. The classification of objects in the context of realization of concepts of value and socially responsible expenses is proposed in order to organize to rationally organize case-by-case social accounting. The originality and practical significance of the research are determined by the development of underlying assumptions of the development of social accounting methodology, oriented to ensuring social responsibility of the enterprise and scientific and methodical recommendations for the classification of socially responsible expenses. Conclusions and perspectives of further research. Taking into account the need sofdifferent stakeholders for disclosingin formation about effectiveness of the economic, social and ecological activity of entities, further researches will be focused on elucidation of the methodical basis of the organization of accounting for socially responsible expenses.

Key words:

social accounting, non-financial reporting, users'needs, international standards of social accounting, socially responsible expenses, objects of social accounting.

\section{СОЦИАЛЬНЫЙ УЧЕТ КАК ИНСТРУМЕНТ СОЦИАЛЬНОЙ ОТВЕТСТВЕННОСТИ ПРЕДПРИЯТИЙ}

Постановка проблемы.. Раскрытие информации о социальной ответственности требует формирования модели социального учета и обоснование специфических инструментов, позволяющих отражать доходы и расходы, связанные с социально ответственной деятельностью предприятия. Целью статьи научное обоснование предпосылок, исходных положений и приоритетных направлений организации социального учета. Объектом исследования выступает процесс учета социальной ответственности. Memoдbl, использованные в исследовании: научного обобщения, логическисодержательный, индукции и дедукции, анализа. Гипотеза исследования предположение, что социальный учет должен быть ориентирован на раскрытие информации о социально ответственной деятельности для различных пользователей и составления интегрированной отчетности. Изложение основного материала. Повышение социальной ответственности предприятий обусловливает необходимость трансформации бухгалтерского учета с целью предоставления прозрачной информации о социальной и экологической деятельности для различных групп пользователей, а также составление интегрированной отчетности. Основой развития методологии социального учета являются концепции социальной ответственности, устойчивого развития, создания ценности, уточнены объекты и классификация социально ответственных расходов. Доказано, что рациональной является модель комбинированного социально ориентированного учета, которая предусматривает параллельное отражение в бухгалтерском учете хозяйственных операций, связанных с социальной деятельностью на основе дополнительной системы аналитических счетов, формирование показателей финансовой и социальной отчетности. С целью рациональной организации пообъектного социального учета предложена классификация объектов в контексте реализации концепции ценности и соціально ответственных расходов. Оригинальность и практическое значение определяются разработкой исходных положений развития методологи соціального учета, ориентированного на обеспечение социальной ответственности предприятия и научно-методических рекомендаций по классификации социально ответственных расходов. Выводы и перспективы дальнейших исследований. Учитывая потребности различных заинтересованных лиц в раскрытии информации о результативности экономической, социальной и экологической деятельности хозяйствующих субъектов, дальнейшие исследования будут посвящены освещению методических положений по организации учета социально ответственных расходов.

Ключевые слова:

социальный учет, нефинансовая отчетность, потребности пользователей, международные стандарты социального учета, социально ответственные расходы, объекты социального учета.

Постановка проблеми. На сучасному етапі зростає роль корпоративної соціальної відповідальності у забезпеченні сталого розвитку підприємств.Суспільство та стейкхол- 
дери зацікавлені в отриманні інформації щодо результативності соціальної та екологічної діяльності підприємств. Публічне розкриття інформації у звітності сприяє покращенню іміджу підприємства, підвищенню конкурентоспроможності, інвестиційної привабливості, гармонізації інтересів зі стейкхолдерами.

Міжнародні стандарти та нормативні документи, що стосуються різноманітних аспектів соціальної відповідальності бізнесу (СВБ) містять вимоги щодо надання інформації зацікавленим сторонам, проте не надають конкретних рекомендацій для формування системи соціального обліку. Проте, вони Міжнародний стандарт ISO 26000 [1] визначає основні напрями та принципи соціально відповідальної діяльності підприємств. Цей стандарт інтегрує рекомендації та вимоги стандартів серії ISO: ISO 9000 «Системи управління якістю» [2], ISO 14000 «Системи менеджменту навколишнього середовища» [3], SA 8000 “Соціальна відповідальність» [4].В Україні відсутнє нормативно-правове регулювання сфери соціальної відповідальності бізнесу.Показники соціально відповідального бізнесу викладено у відповідному Меморандумі, змістяких базується на принципах Глобального Договору ООН, вимогах діючих документів ЕвпропейськогоСоюзу та українського законодавства [1]. Стандарт ISO 26000 та визначені критерії СВБ $є$ основою формування облікового забезпечення корпоративної соціальної відповідальності бізнесу.

Показники, що характеризують корпоративну соціальну відповідальність частково розкриваються великими вітчизняними компаніями у корпоративній звітності. У бухгалтерському обліку відображаються лише окремі аспекти про екологічну і соціальну діяльність підприємств, що знижує можливості подолання конфлікту інтересів різних груп зацікавлених осіб. Мова йде про необхідність трансформації бухгалтерського обліку з метою формування інформації щодо соціальної відповідальності підприємства для складання інтегрованоїкорпоративної звітності.

Аналіз останніх досліджень та публікацій. 3 появою концепції сталого розвитку дослідженням у сфері корпоративної соціальної відповідальності присвячена велика кількість наукових праць зарубіжних та вітчизняних вчених, серед яких М. Фрідман [5], А. Керолл [6], Г. Боуен [7], О. Левченко та I. Міщенко [8], I. Клименко [9].
Різні аспекти соціально орієнтованого обліку розкриті у наукових працях вітчизняних вчених: С. Король [10], К. Галак [11], О. Сокіл [12], І. Омецінська [13], С. Петренко [14].Значний внесок у розвиток обліковоаналітичного забезпечення соціальною відповідальною діяльністю зробила С. Король [10], в наукових працях якої розкрито методологічну платформу бухгалтерського обліку, функціональний потенціал бухгалтерського обліку, класифікація показників звіту зі сталого розвитку, інтегративний підхід до формування обліково-інформаційного забезпечення складання нефінансової та спеціальної управлінської звітності. К. Галак [11]робить акцент на виділення обліку витрат соціально орієнтованої діяльності в окрему підсистему 3 метою прийняття раціональних управлінських рішень та розкриває теоретичні підходи до формування облікової політики, методичні підходи до побудови аналітичного обліку 3 метою забезпечення деталізованого обліку витрат соціально орієнтованої діяльності.

О.Г. Соколом [12]обгрунтовано концептуальні основи трансформації бухгалтерського обліку та його основні складові: внутрішній та зовнішній бухгалтерський облік сталого розвитку. Лаговською О.А. [25] висвітлено підходи до класифікації об'єктів соціально орієнтованого обліку. С.Петренко та В. Бесарабовим [14] узагальнено моделі, зміст і порядок складання соціальної звітності.Разом з тим слід визнати необхідність подальшого дослідження таких важливих питань як: методичні положення обліку соціальної відповідальності, класифікація витрат 3 позиції впливу на додану вартість.

Метою статті снаукове обгрунтування передумов, вихідних положень та пріоритетних напрямків організації соціального обліку як інструменту соціальної відповідальності підприємств.

Виклад основного матеріалу дослідження.Результати дослідження свідчать про підвищення активності соціально відповідальної діяльності вітчизняних суб'єктів господарювання, що підтверджуються зростанням громадської активності бізнесу, у 2018-2019 роках, 31 компанія витратила понад 411 млн.грн. на соціальні проекти. У пріоритеті бізнесу - допомога організаціям в освітніх проектах (89\%), поліпшення умов праці $(71 \%)$ і ініціативи у сфері екології $(62,5 \%)$ [15]. Розвиток СВД зумовлює необхідність забезпечення користувачів відповід- 
ною інформацією через системусоціального обліку, орієнтованого на формування інформації про господарські операції щодо витрат та результатів соціально відповідальної діяльності підприємства і складання соціальної звітності. При цьому слід підкреслити, що відображення господарських операцій у бухгалтерському облікуносить динамічний характер, то соціальний облік відповідно до стандартівКСВ відображає тільки результативні показникита сприяє підвищенню ділової репутації.

Передумови соціального обліку підприємств полягають у наступному:

- забезпечення сталого розвитку та підвищення ділової репутації;

- потреба у комунікації із стейкхолдерами на основі прозорої інформації щодо соціальних інвестицій, витрат і економічних вигід, пов'язаних $з$ соціально відповідальною діяльністю через іiі оприлюднення в нефінансовій звітності;

- формування інформації для потреб планування, стимулювання, регулювання, аналізу і контролю соціально відповідальної діяльності;

- відображення витрат та результатів соціально відповідальної діяльності у бухгалтерському обліку і звітності;

- оцінка зовнішніх та внутрішніх ефектів впливу соціально відповідальної діяльності на фінансові результати підприємства та зовнішне середовище;

- аналіз і оцінка ефективності використання фінансового, природного і соціального капіталів підприємства 3 метою розкриття інформації щодо реалізації політики дотримання сумлінної взаємодії зі всіма зацікавленими сторонами.

При цьому слід підкреслити, що основними проблемами, що перешкоджають раціональній організаціїсоціального обліку є:неповне розкриття інформації про соціальну діяльність підприємства; розбіжності між вітчизняними та міжнародними стандартами бухгалтерського обліку щодо відображення соціально відповідальних витрат; відсутність єдиної класифікації соціально відповідальних витрат; нераціональний розподіл витрат на соціальну та екологічну діяльність, неврегульованість обліку понаднормативних соціальних витрат; відсутність необхідного досвіду у складанні соціальної звітності.У положенні (стандарті) бухгалтерського обліку П(С)БО 16 «Витрати» [16] є тільки соціальні відповідальні витрати не виокремлені із загальної сукупності витрат. Вони знаходяться у складі прямих витрат на оплату праці (заробітна плата, відрахування на соціальні заходи,) та загальновиробничих витрат. Окремі аспекти обліку витрат на утримання та розвиток персоналу регулюються П(С)БО 26 "Виплати працівникам» [17], де визначається порядок формування у бухгалтерському обліку інформації про поточні виплати, виплати при звільненні, виплати по закінченні трудової діяльності, виплати інструментами власного капіталу підприємства, інші довгострокові виплати;

Розвиток методології соціальногообліку розглядаєтьсяз позицій концепцій соціальної відповідальності,сталого розвитку, створення цінності та уточнення об’єктів і класифікації витрат соціально відповідальної діяльності. Вихідні методологічні положення соціального обліку полягають у такому(табл. 1).

1) фокусування на формуванні інформації для підготовки та складання соціальної звітності залежно від інтересів та потреб зацікавлених осіб;

2) розширення предметного поля бухгалтерського обліку за рахунок класифікації об'єктів соціального обліку за напрямками СВД;

3) використання специфічних інструментів і моделей обліку і аналізу результатів діяльності підприємств;

4) методологія соціального обліку реалізується на основі узгодженості методів конкретної предметної сфери, яка відповідає напрямкам та об'єктам СВД.

Головна мета соціально орієнтованого обліку - формування достовірної і неупередженої інформації щодо результативності соціально відповідальної діяльності підприємства для зовнішніх і внутрішніх користувачів.

Предмет соціально орієнтованого обліку співпадає 3 предметом бухгалтерського обліку СВД. Протеметодологія соціального обліку не збігається з методологією бухгалтерського обліку у зв'язку з тим, що в значній мірі домінують методи управлінського обліку при формуванні нефінансової інформації, а також використання математичних моделей i аналітичних процедур. Це вимагає розробку відповідноїмоделі та вдосконалення інструментарію соціального обліку. 
Вихідні положення соціального обліку

\begin{tabular}{|c|c|}
\hline \multicolumn{2}{|c|}{ Вихідні положення } \\
\hline Положення & Характеристика \\
\hline $\begin{array}{l}\text { Робоча гіпотеза дос- } \\
\text { лідження }\end{array}$ & $\begin{array}{l}\text { Припущення про: необхідність виділення об’єктів і показників, що впливають } \\
\text { на СВД; відповідність методів предметній області напрямам та об’єкту дослі- } \\
\text { дження }\end{array}$ \\
\hline $\begin{array}{l}\text { Предмет методології } \\
\text { соціального обліку }\end{array}$ & $\begin{array}{l}\text { Формування категорій: об’єкт, суб’єкт, процес і елементи СВД, методи, пока- } \\
\text { зники }\end{array}$ \\
\hline Мета & $\begin{array}{l}\text { Надання зацікавленим користувачам інформації про результативність еконо- } \\
\text { мічної, соціальної та екологічної діяльності }\end{array}$ \\
\hline Об’єкти & $\begin{array}{l}\text { Активи, зобов'язання, доходи, витрати, власний капітал, господарські опера- } \\
\text { ції СВД }\end{array}$ \\
\hline Завдання & Обліково-аналітичне забезпечення підготовки соціальної звітності \\
\hline $\begin{array}{l}\text { Методологічне за- } \\
\text { безпечення }\end{array}$ & $\begin{array}{l}\text { ISO26000 «Керівництво із соціальної відповідальності», ISO } 9000 \text { «Системи } \\
\text { управління якістю», ISO } 14000 \text { «Системи менеджменту навколишнього сере- } \\
\text { довища», ISO } 18001 \text { «Системи менеджменту гігієни та безпеки праці», SA } \\
8000 \text { “Соціальна відповідальність» }\end{array}$ \\
\hline Модель організації & Комбінована \\
\hline Користувачі & $\begin{array}{l}\text { Власники, працівники, контрагенти, інвестори, органи державної влади, сус- } \\
\text { пільство }\end{array}$ \\
\hline Показники & $\begin{array}{l}\text { 1) Показники, визначені на основі даних бухгалтерського обліку; } \\
\text { 2) Показники, визначені на основі даних соціального обліку; } \\
\text { 3) Показники, визначені на основі аналітичних розрахунків }\end{array}$ \\
\hline Методи & $\begin{array}{l}\text { Документування та інвентаризація, оцінки і калькуляції, аналітичних розра- } \\
\text { хунків, балансові, статистичні }\end{array}$ \\
\hline $\begin{array}{l}\text { Використання даних } \\
\text { соціального обліку }\end{array}$ & Підготовка та складання соціальної звітності \\
\hline
\end{tabular}

Джерело: розроблено авторами

Розвиток сучасних досліджень соціального обліку свідчить про наявність 3 моделей [14, с. 172-174]: 1) соціально орієнтований бухгалтерський облік - базується на інформації, яка формується у системі бухгалтерського обліку, пов'язаної з відображенням соціально відповідальної діяльності, які наприкінці звітного періоду трансформуються у показники фінансової і соціальної звітності; 2) комбінований соціально орієнтований облік передбачає паралельне ведення з бухгалтерським обліком на основі додаткової системи аналітичних рахунків, формування показників фінансової і соціальної звітності $з$ деякими поправками на величину витрат соціально відповідальною діяльністю; 3) абсолютний соціальний облік - орієнтований на паралельне ведення локального соціального обліку поряд 3 бухгалтерським обліком на основі єдиного масиву первинної інформації. На основі порівняння вказаних моделей зроблено висновок, що найбільш придатною $є$ змішана модель соціального обліку, підгрунтям якої $є$ процесно-функціональний підхід, що передбачає організацію соціального обліку за функціями управління і напрямками соціаль- ної відповідальності підприємства, оскільки між екологічною і соціальною діяльністю не існує чітких меж.

Організація соціального обліку охоплює розробку моделі та обгрунтування інструментів, класифікацію об'єктів та витрат соціально відповідальної діяльності.

Базуючись на процеснофункціональному підходіоб'єкти обліку слід класифікувати наступними чином:фактори виробництва, господарськіоперації, джерела господарських засобів, результати у розрізі соціальної та екологічної діяльності [18]. Такий підхід розкриває взаємозв'язокміж ресурсами, процесами та підрозділами ітому може використовуватися для визначення об' єктів соціально відповідальної діяльності.

В класифікації об'єктів обліку соціальної діяльності, яка запропонована I. Жиглей [19], визначальною характеристикою $є$ групи господарських операцій, що забезпечують внутрішню та зовнішню соціально відповідальну діяльність. В межах управлінського обліку об' єктами виділені господарські операції, які ідентифікують надання працівнику виплат в рамках соціального пакету.Об'єкти бухгал- 
терського обліку соціально відповідальної діяльності класифікуються на об'єкти, які забезпечують господарську діяльність (господарські засоби та їх джерела) і об'єкти, які складають господарську діяльність (господарські процеси та їх результати).

Результати дослідження дозволили згрупувати об'єкти соціального обліку наступним чином: 1) ресурси за видами активів та джерела їх формування; 2) фактори виробництва, господарські процеси та результати; 3)доходи та витрати за напрямами соціально відповідального бізнесу. Перелік об'єктів соціальних витрат можна розширювати, а також додатково виділяти соціальні та екологічні характеристики в операційній, фінансовій та інвестиційній діяльності підприємств. Погоджуємося $з$ О.І. Коблянською [20, с. 213] та Д.О. Грицишен [21, с. 450], які пропонують вести бухгалтерський облік екологічних зобов'язань за таких обставин: 1) нарахування плати за використанняприродних ресурсів; 2) невиконання вимог чинного екологічногозаконодавства, що призводить до необхідності компенсації завданоїшкоди, виплати штрафів; 3) усунення негативних наслідків впливупідприємств на навколишнє середовище 4) оподаткування екологічно шкідливої продукції; 5) надання додаткових пільг за умов здійснення суб'єктами господарювання природоохоронних програм, упровадження екобезпечної техніки й технології виробництва»

3 метою надання достовірної інформації для складання соціальної звітності актуа- льним є виокремлення непередбачених господарських операцій та їх наслідків у сфері соціальної та екологічної діяльності, що призводять до зміни вартості підприємства.До таких об'єктів відносяться: непередбачені зобов'язання/активи в частині потенційних або незавершених (на звітну дату) судових справ за екологічними питаннями; непередбачені зобов'язання/активи, пов'язані 3 відновленням забрудненого навколишнього середовища та усуненням негативних наслідків екологічного характеру; непередбачені зобов'язання, пов'язані змайбутніми змінами норм чинного законодавства, державної політики,які зумовлюють виникнення нових екологічних зобов'язань або призводять до збільшення розміру існуючих; непередбачені зобов'язання, спричинені припиненням або призупиненням діяльності підприємства, викликаних недотриманням норм екологічного характеру, визначених чинним законодавством [18].

Раціональна організація пооб’єктного соціального обліку потребує деталізації інформації за кожним напрямком облікового процесу. Виходячи 3 того, що соціальні витрати суб'єктів господарювання є значними, тому актуальним є виділення такого об'єкту обліку як соціально відповідальні витрати та упорядкування їх класифікації. Для організації пооб'єктного обліку соціально відповідальних витрат упорядкована класифікація витрат СВД за об'єктами і джерелами їх покриття наведена в табл. 2.

Т а б ли ц я 2

Класифікація соціально відповідальних витрат за об'сктами і джерелами покриття

\begin{tabular}{|c|c|c|}
\hline $\begin{array}{c}\text { Об'єкти, } \\
\text { напрямки СВД }\end{array}$ & Витрати СВД & Джерела їх покриття \\
\hline 1 & 2 & 3 \\
\hline Працівники & $\begin{array}{l}\text { Витрати на оплату праці } \\
\text { Витрати на «соціальний» пакет і персонал } \\
\text { Витрати на недержавне пенсійне страхування } \\
\text { Витрати на охорону здоров’я працівників } \\
\text { Витрати на охорону праці на підприємстві } \\
\text { Витрати на санаторно-курортне забезпечення } \\
\text { Витрати на організацію дозвілля персоналу }\end{array}$ & $\begin{array}{l}\text { Собівартість готової продукції } \\
\text { Соціальні інвестиції } \\
\text { Спонсорські внески } \\
\text { Соціальне підприємництво }\end{array}$ \\
\hline Власники & Витрати на виплату дивідендів & Чистий прибуток \\
\hline Споживачі & $\begin{array}{l}\text { Інвестиції в систему менеджменту якості } \\
\text { Витрати на вдосконалення матеріально- } \\
\text { технічної бази виробництва } \\
\text { Витрати на запровадження нових технологій } \\
\text { виробництва } \\
\text { Витрати на проведення інноваційних дослі- } \\
\text { джень у сфері діяльності } \\
\text { Витрати на рекламу }\end{array}$ & $\begin{array}{l}\text { Собівартість реалізованої про- } \\
\text { дукції } \\
\text { Виручка від реалізації продук- } \\
\text { ції }\end{array}$ \\
\hline
\end{tabular}




\begin{tabular}{|c|l|l|}
\hline 1 & \multicolumn{1}{|c|}{2} & \multicolumn{1}{|c|}{3} \\
\hline Постачальники & $\begin{array}{l}\text { Витрати на сплату штрафів за порушення дого- } \\
\text { вірних зобов’язань } \\
\text { Витрати на збут товарів та послуг }\end{array}$ & $\begin{array}{l}\text { Собівартість реалізованої } \\
\text { продукції } \\
\text { Виручка від реалізації продукції }\end{array}$ \\
\hline Суспільство & $\begin{array}{l}\text { Витрати на благодійну допомогу } \\
\text { Витрати на збереження довкілля } \\
\text { Витрати на впровадження енергозберігаючих } \\
\text { технологій } \\
\text { Витрати на спонсорську діяльність } \\
\text { Витрати на розвиток місцевої громади }\end{array}$ & $\begin{array}{l}\text { Виручка від реалізації } \\
\text { Систий прибуток }\end{array}$ \\
& $\begin{array}{l}\text { Содаткість готової продукції } \\
\text { Витрати на сплату ЄСВ } \\
\text { Витрати на сплату екологічного податку } \\
\text { Витрати на сплату штрафів за порушення еко- } \\
\text { логічного законодавства } \\
\text { Витрати на сплату штрафів за несвоєчасну або } \\
\text { неповну сплату податків }\end{array}$ & $\begin{array}{l}\text { Собівартість продукції } \\
\text { Чистий прибуток }\end{array}$ \\
\hline
\end{tabular}

\section{Джерело: розроблено авторами на підставі $[22,23]$}

Складання інтегрованої корпоративної звітності обумовлює розширення інформації про витрати та доходи, що стосуються економічної, соціальної та екологічної діяльністю та не враховуються в межах традиційного обліку. Інформація, пов'язана 3 доходами та витратами зовнішнього впливу, сформована у межах внутрішнього бухгалтерського обліку, дозволяє встановити зв'язок між прихованими витратами і вигодами та фінансовою ефективністю для прийняття управлінських рішень. Вплив на організацію інтерналізується як втрачена продуктивність і може бути врахована в одному 3 внутрішніх рахунків сталості. Узагальнення зовнішніх втрат і вигід для навколишнього середовища, суспільства й суб'єктів господарювання вимагає трансформації існуючого плану рахунків[12, с. 402].Виходячи 3 того, що соціально відповідальні витрати призводять до економічних вигід, необхідно виділення соціально відповідальних витрат у відповідності із впливом на додану вартість підприємства, тобто на продуктивні витрати, що додають вартість, i непродуктивні, що не додають вартість. Придатність такої класифікації обумовлена необхідністю: виявлення “виправданих" i “невиправданих" витрат шляхом співставлення корисного ефекту (зростання фінансових результатів) і витрат; ідентифікації резервів зниження витрат за рахунок ліквідації непотрібних функцій; прийняття рішень щодо раціонального розподілу витрат; оцінки ступеню ризику недоотримання запланованого прибутку. При складанні фінансової звітності різниця між первісним і реальним значенням фінансового результату є втратами, на які повинен бути сформований резерв для його корегування на майбутнє.

Наведена деталізація витрат за вказаними ознаками $є$ підгрунтям організації обліку соціально відповідальних витрат за видами діяльності та вибору управлінських рішень щодо раціонального розподілу ресурсів.

Висновки та перспективи подальших досліджень. Підвищення соціальної відповідальності бізнесу вимагає розкриття прозорої інформації щодо результативності соціальної та екологічної діяльності підприємства для зовнішніх i внутрішніх користувачів.У сучасній методології вітчизняного бухгалтерського обліку відсутні окремі елементи, які відображають всі аспекти соціально відповідальної діяльності підприємств, зокрема соціально відповідальні витрати та доходи, сформовані за рахунок СВД. Доведено, що організацію обліку соціально відповідальної діяльності доцільно здійснювати за такими напрямками: ідентифікація та класифікація об'єктів обліку відповідно до інформаційних потреб стейкхолдерів; класифікація соціально відповідальних витрат за напрямками i джерелами витрат. Запропонована модель комбінованого соціального обліку, на основі процесно-функціонального підходу дозволяє: по-перше, концентрувати увагу на об'єктах за функціями управління та сферами соціально відповідальної діяльності; по-друге, визначати результативність соціальної та екологічної діяльності і формувати інформацію для скла- 
дання інтегрованої корпоративної звітності, окремим підрозділом якої $є$ соціальна звітність. що складається на основі даних бухгалтерського і соціального обліку.

\section{Література}

1. ISO 26000 Internationalstandard: Guidance on social responsibility. URL: https://iso26000.info/wpcontent/uploads/2017/06/ISO-

26000_2010_E_OBPpages.pdf (дата звернення: 11.01.2020 p.)

tem»

2. ISO9000 «Management quality sysURL:https://khoda.gov.ua/image/catalog/files/\% 209000.pdf (дата звернення: 10.01.2020р.)

3. ISO 14000 «Environmental management». URL: https://friedman.com.ua/wpcontent/uploads/2017/09/ISO14000.pdf (дата звернення: 11.01 .2020 р.)

URL:

4. SA 8000 «Social Responsibility».

https://zakon.rada.gov.ua/laws/show/n0015697-0 (дата звернення: 12.01 .2020 р.)

5. Fridman M. The Social Responsibility of Business is to increase its Profits. New York Yimes Magazine. - September, 13.1970. P.122-126.

6. Carroll A.B. 1979. A threedimensional conceptual model of corporate performance. Academy of Management Review 4(4), p. 497-505.

7. Bowen Howard R. Social Responsibilities of the Businessman. N.Y.: Harper \& Row, 1953. 298 p.

8. Левченко О.П., Міщенко І.В. Етапи формування стратегії корпоративної соціальної відповідальності (КСВ) підприємства. Економіка транспортного комплексу. 2015. Вип. 25. С. 36-49.

9. Клименко І.М. Теоретикометодологічний підхід до ролі соціальної відповідальності бізнесу у сучасних умовах. Інвестииї: практика та досвід. 2018. №8. C.118-124.

10. Король С.Я. Теоретичні засади соціального обліку. Облік і фінанси, 2016. №2 (72). C. 29-34.

11. Галак К.І. Особливості методики обліку витрат соціально-орієнтованої діяльності. Економіка. Фінанси. Право. 2017. № 9/2. C. $15-20$.

12. Сокіл О.Г. Концептуальні основи методології трансформації традиційної си- стеми обліку у бухгалтерський облік сталого розвитку. Проблеми економіки. 2017. № 1. С. 398-403.

13. Омецінська І.Я. Облік як інформаційна база для реалізації соціальної політики в управлінні підприємством. Вісник Тернопільського нащіонального економічного університету. 2017. № 4. С. 125-137.

14. Петренко С.Н., Бесарабов В.О. Модель построения социально ориентированного бухгалтерскогоучета и отчетности: организационная компонента. Вестник Пермского университета. 2015. Вып. 4(27). C. 170-178.

15. Писк моди: КСВ в Україні набирає обертів: Сьогодні: новини компаній. URL: https://www.segodnya.ua/ua/ukraine/piskmody-kso-v-ukraine-nabiraet-oboroty-

1343574.html (дата звернення: 11.01.2020р.)

16. Положення (стандарт) бухгалтерського обліку 16 "Витрати": наказ Міністерства фінансів України від 31 грудня 1999 р. № 318. URL: https://zakon.help/law/318/(дата звернення: 10.01.2020 p.)

17. Положення (стандарт) бухгалтерськогообліку 26 «Виплати працівникам» наказ МіністерствафінансівУкраїнивід 28 жовтня 2003 p. № 601. URL: https://zakon.help/law/z1025-03/(дата звернення: 13.01.2020 p.)

18. Лаговська О.А. Обліковоаналітичне забезпечення вартісноорієнтованого управління: теорія та методологія: монографія. Житомир: ЖДТУ, 2012. $-676 \mathrm{c}$.

19. Жиглей I. В. Бухгалтерський облік соиіально відповідальної діяльності суб'єктів господарювання: необхідність та орієнтири розвитку: монографія. Житомир: ЖДТУ, 2010. $536 \mathrm{c.}$

20. Коблянська О.І. Актуальні аспекти обліку екологічних зобов'язань. Вісник Університету банківської справи НБУ. 2014. № 2 (20). C. 212-214.

21. Грицишен Д.О. Склад об'єктів та розвиток методу бухгалтерського обліку господарської діяльності як соціальноеколого-економічної системи. Проблеми теорії та методології бухгалтерського обліку, контролю і аналізу. 2015. Вип. 1(31). C. $442-466$.

22. Дєліні М.М. Показники оцінки соціально-економічної відповідальності підприємства в Україні. Проблеми економіки. 2017. №4. C. 263-270. 
23. Аммарі А.О. Класифікація стейкхолдерів на основі взаємних очікувань. Актуальні проблеми економіки. 2012. №8(134). С. 150-155.

\section{References}

1. ISO 26000 Internationalstandard: Guidance on social responsibility. URL: https://iso26000.info/wpcontent/uploads/2017/06/ISO26000_2010_E_OBPpages.pdf

2. ISO9000 «Management quality system»

URL:https://khoda.gov.ua/image/catalog/files/\%20 9000.pdf

3. ISO 14000 «Environmental management». URL: https://friedman.com.ua/wpcontent/uploads/2017/09/ISO14000.pdf

4. SA 8000 «Social Responsibility». URL: https://zakon.rada.gov.ua/laws/show/n0015697-0

5. Fridman, M. (1970). The Social Responsibility of Business is to increase its Profits. New York Yimes Magazine. - September, 13. P.122-126.

6. Carroll, A.B. (1979). A threedimensional conceptual model of corporate performance. Academy of Management Review 4(4): 497-505.

7. Bowen, Howard R. (1953) Social Responsibilities of the Businessman / H.R. Bowen. N.Y.: Harper \& Row. 298 p.

8. Levchenko, O.P., \&Mishchenko, I.V. (2015). Stages of formating strategy of corporate social responsibility (CSR) of enterprise. The economy of transport complex, 25, 36-49.

9. Klymenko, I.M. (2018) Theoretical and methodological approach to the role of social responsibility of business in modern conditions.Investments: practice and experience, 8,118 124.

10. Korol, S. Ya. (2016)Theoretical basis of social accounting. Accounting and finance, 2(72), 29-34

11. Galak, K.I. (2017) The features of method of accounting expenses of socially oriented activity. Economy. Finance. Law, 9/2, 15-20

12. Sokil, O. G. (2018). Conceptual frame works of the methodology of traditional accounting

Стаття надійшла

до редакції : 06.01.2020 p. system transformation to sustainable development accounting. Problems of economy, 1,398-403.

13. Ometsinska, I. Ya. (2017). Accounting as informational base for implementation of social policy in managing enterprise. Bulletin Ternopil national economic university, 4, 125-137.

14. Petrenko, S.N. \& Besarabov, V.O. (2015). Model of building socially oriented accounting and reporting: organizational component. Bulletin of Perm university, 4(27), 170-178.

15. Squeak of fashion: CSR in Ukraine gains momentum: Yesterday: thenews of companies.

URL:

https://www.segodnya.ua/ua/ukraine/pisk-modykso-v-ukraine-nabiraet-oboroty-1343574.html

16. Ukrainian accounting standart $16 \ll \mathrm{Ex}-$ penses»: order of Ministry of finance of Ukraine on December, 31, 1999 № 318. URL: https://zakon.help/law/318/

17. Ukrainian accounting standart $26 \ll$ Repayments to workers $»$ : order of Ministry of finance of Ukraine on October 28, 2003, №601 URL: https://zakon.help/law/z1025-03/

18. Lagovska, O.A. (2012) Accounting and analytical support for value-based management: theory and methodology. Monograph. Zhytomyr. ZhDTU, 676.

19. Zhygley, I. V. (2010) The accounting of socially responsible activity of entities: necessity and the guides of development: monograph. Zhytomyr: ZhSTU, 536

20. Koblyanska, O.I. (2014) The actual aspects of accounting ecological liabilities. The bulletin of National bank of Ukraine Banking University.2(20).212-214.

21. Hrytsyshen, D. O. (2015). The composition of object sand the development of method of accounting the economic activity as the social, ecological and economic system.Problems of theory and methodology of accounting, control and analysis, 1(31), 442-466.

22. Delini, M.M. (2017) The indicatorsforassessingsocialandeconomicresponsibilityofenterpriseinUkraine. 4,263-270.

23. Ammari, A.O. (2012). Stakeholders'classification based on mutual expectations. The actual problems of econom.

Стаття прийнята

до друку: 27.02.2020 p.

\section{Бібліографічний опис для цитування :}

Костирко Р. О. Соціальний облік як інструмент соціальної відповідальності підприємств / Р. О. Костирко, Д. В. Прозоров // Часопис економічних реформ. - 2020. - № 1 (37). - С. 74-82. 